\title{
State presence in the credit market: state-owned banks and earmarked credit in the 2008 crisis $^{*}$
}

\author{
Lucas A. B. de C. Barros ${ }^{1}$ \\ (D) https://orcid.org/0000-0002-9319-1306 \\ Email: lucasbarros@usp.br
}

\section{Catarina Karen dos Santos Silva ${ }^{2}$ \\ (D) https://orcid.org/0000-0002-0681-2822 \\ Email: catarinakaren@gmail.com}

\author{
Raquel de Freitas Oliveira ${ }^{3}$ \\ (D) https://orcid.org/0000-0003-3941-7690 \\ Email: raquel.oliveira@bcb.gov.br
}

\author{
${ }^{1}$ Universidade de São Paulo, Faculdade de Economia, Administração e Contabilidade, Departamento de Contabilidade e Atuária, São Paulo, SP, \\ Brazil \\ ${ }^{2}$ Itaú Unibanco S.A., São Paulo, SP, Brazil \\ ${ }^{3}$ Banco Central do Brasil, Departamento de Estudos e Pesquisas, São Paulo, SP, Brazil
}

Received on 01.30.2020 - Desk acceptance on 02.27.2020 - $2^{\text {nd }}$ version approved on 12.23.2020 - Ahead of print on 06.25.2021

Editor-in-Chief: Fábio Frezatti

Associate Editor: Fernanda Finotti Cordeiro

\begin{abstract}
The objective of this study was to document the relationship between the two mechanisms of state action (credit earmarking and corporate control of banks) and the granting of bank credit in Brazil during the 2008 global financial crisis. There is an intense debate in the literature about the effectiveness of the State's role in the financial system and its effects on the economy. One aspect of this issue is identifying whether the state presence contributes to stabilizing the granting of credit and softening financial crises' economic impact. The studies carried out to date have not considered the differences between free and earmarked credits at the bank level, nor their possible interaction with the type of bank property. The study's subject is relevant because it can help guide counter-cyclical public policies to face crises, including the use of changes in credit earmarking or state-owned banks' performance. The analyses carried out can inform the debate about the pros and cons of the state's presence in the credit market. The study analyses data from 2005 to 2012 from financial institutions that capture deposits from the public. Inferences are based on linear regression models, including a wide range of control variables. This study documents a significant reduction in credit granted by private banks in Brazil and state-owned banks' expansion during the 2008 crisis. This evidence is not only due to differences in the funding rate during the period or to economic fundamentals, suggesting that the effect of corporate control is possibly related to the counter-cyclical performance of state-owned banks. The results show that the credit earmarking mechanisms were not particularly relevant in smoothing the contraction resulting from the financial crisis.
\end{abstract}

Keywords: earmarked credit, bank credit, state-owned banks, financial crisis.

Correspondence address

Lucas A. B. de C. Barros

Universidade de São Paulo, Faculdade de Economia, Administração e Contabilidade, Departamento de Contabilidade e Atuária

Avenida Professor Luciano Gualberto, 908 - CEP 05508-010

Cidade Universitária - São Paulo - SP - Brazil

*Work presented at the XVIII Brazilian Finance Meeting, São Paulo, SP, Brazil, July 2018. 


\section{INTRODUCTION}

There is an intense debate about the effectiveness of the State's activities in the financial system and its effects on economic growth. One aspect of this issue is identifying whether the government presence contributes to stabilizing credit granting and softening the negative shock of financial crises on economic activity. There are two mechanisms of state action in the credit market in Brazil: credit earmarking and banks' corporate control. The earmarking allocates credit to specific sectors or activities determined by the law or regulations (Lundberg, 2011).

If, on the one hand, the literature suggests the existence of counter-cyclical behavior by state-controlled banks (e.g., Allen et al., 2017; Brei \& Schclarek, 2013; Chen et al., 2016; Fungáčová et al., 2013), on the other hand, the role of earmarked credit policies in stabilizing the granting of credit in crises is still under-examined. For example, Bonomo et al. (2014) investigate the determinants of firms' access to earmarked loans and their consequences concerning investments, indebtedness, and financial expense reduction. We do not know studies that focus on the effects of the interaction between credit earmarking and the type of bank ownership.

The purpose of this research is to document the relationship between the two channels of state action and the granting of bank credit in Brazil during the 2008 global financial crisis, known as the subprime crisis. The 2008 crisis was a global event essentially exogenous to the Brazilian financial system (Oliveira et al., 2015) and therefore offers a unique opportunity to investigate whether (i) the bank's state ownership and (ii) earmarked credit policies contribute to the smoothing of the credit supply. The interaction between the type of property and the type of credit granted (free or earmarked) is also investigated, something unprecedented in the literature.

When the state has corporate control of banks, it can quickly adjust credit policies to its needs. Thus, state ownership is a direct way of operating in the credit market. In the context of the 2008 crisis, state-owned banks expanded credit in Latin America (Cull \& Martínez Pería, 2013), Central and Eastern europe (Allen et al., 2017), and Russia (Fungáčová et al., 2013), whereas private banks reduced credit.

On the other hand, earmarking is an indirect way of operating in the credit market independent of bank ownership. In Brazil, earmarking is carried out through voluntary and mandatory mechanisms. In the first case, the government can attract private or state-owned banks by offering incentives as guarantees or equalization of interest rates. Financing that financial institutions offer using BNDES resources falls into this category.

The mandatory earmarking, in turn, originates from liabilities imposed by the government as minimum earmarking percentages levied on demand, time, or savings deposits captured by banks. Basically, these liabilities must be applied in rural credit, microcredit, and real estate financing operations. For example, in 2008, $65 \%$ of savings deposits were to be used for mortgage loans. In non-compliance with the determined conditions (deficiencies), penalties may be imposed, usually linked to additional reserve requirements or fines (BCB, 2014).

Our analyses suggest that, like other countries, banks' state ownership has significantly mitigated the negative impact of the 2008 crisis on credit granting. The average growth rates for state-owned bank loans (both total and in the mandatory earmarked category) were substantially higher during the acute phase of the crisis.

The relationship between loan growth and the bank's ownership survives the inclusion of other observable and unobservable banks' characteristics, including the growth rate of funding. The average growth rate for total loans is approximately 12 percentage points (p.p.) higher for state-owned banks than private banks. On the other hand, the average growth rate of total loans to private banks during the crisis is approximately 9 p.p. lower compared to the other periods.

This evidence is in line with Brei and Schclarek's (2015) theoretical analysis of state-controlled banks' countercyclical action. They are also compatible with the behavior documented by Schiozer and Oliveira (2016), suggesting that private banks tend to maintain a liquidity buffer during periods of systemic uncertainty. The results show that the expansion of state-owned bank loans occurred similar to loans in the free and mandatory earmarked categories.

Interestingly, our results suggest that government action has bypassed credit earmarking. The proportion of earmarked credit concerning the total credit did not change significantly, on average, during the crisis. The estimated coefficients are not statistically significant at conventional levels, possibly because earmarked credit was small compared to many banks' total credit. Similarly, there is no evidence that the degree of prior participation in earmarked credits significantly affected the average rate of loan growth during the crisis. Taken together, the results suggest that the earmarked credit mechanism did not significantly contribute to mitigating the retraction of private banks in this period. 
This study's main contribution is the joint investigation of two state intervention channels and their interaction. Specifically, of the four works closest to this, two (Lundberg, 2011; Pissetti, 2012) report exclusively descriptive analyzes with data aggregated by type of property and/or type of credit. Annibal et al. (2009), in addition to the descriptive analysis, apply structural break tests to the aggregated time series. Only Coleman and
Feler (2015) use regressions with panel data, similar to those reported in this research, isolating banks' observable and unobservable characteristics. However, the sample and the estimation procedure are different and, especially Coleman and Feler (2015) do not directly control for profitability and growth in funding, two variables relevant in the models reported in this research.

\section{CONTEXT AND THEORETICAL BACKGROUND}

State intervention in the financial system is a controversial topic. La Porta et al. (2002), Brei and Schclarek (2013), and Fungáčová et al. (2013) evaluate the government's participation in the banking market from the perspective of two contrasting views: the developmental view and the political view. Under both, the government finances projects that the private sector would not finance.

However, in the developmental view, projects are socially desirable, and state-owned banks act to compensate for market failures. For example, they finance socially profitable projects with externalities that potentially generate economic growth but are not of interest to private banks (Stiglitz, 1993).

In the political view, state-owned banks act based on providing employment, subsidies, and other benefits that can translate into favors in votes, political contributions, and corruption. According to this view, the government is willing to finance inefficient but politically desirable projects. For example, Dinç (2005), when studying the main emerging countries of the 1990s, concludes that loans from state banks are higher in electoral years relative to private banks, indicating that politicians can use stateowned banks to distribute income to their supporters. Carvalho (2014) and Sapienza (2004) offer similar evidence in Brazil and Italy, respectively.

There is also a wide debate in the literature about the effects of credit earmarking on resource allocation and interest rates in the financial system. One of the main arguments against earmarking is that subsidized rates push up the free market rate, an undesirable effect. The explanation is that banks would feel harmed by the obligation to keep the interest rate of earmarked loans unreasonably low and would increase the interest rates of freely allocated loans to compensate for their losses. Therefore, the credit market's imposition of restrictive conditions can imply hidden fiscal costs, creating distortions (Llanto, Geron \& Tang, 1999).

As mentioned earlier, in Brazil, earmarked loans can be mandatory or voluntary. Lundberg (2011) and
Bonomo et al. (2014) offer detailed descriptions of the country's earmarked credit distribution. In the voluntary mechanism, credit earmarking often occurs through transfers from the BNDES, whose source of funds can be diverse, including funds such as FGTS, FAT, PIS/PASEP (Social Integration Program/Civil Service Asset Formation Program), National Treasury resources, applications, and others. In these transfers, the accredited financial institutions carry out the credit analysis and decide the approval assuming the risk, although, for operations with small and medium-sized companies, there may be an assurance from BNDES FGI - Investment Guarantee Fund (BNDES, 2014). Banks' incentives to act voluntarily as lenders for loans originating from the BNDES assuming the operation's risk are as follows: the payment of the financial intermediation fee and the remuneration and the possible gains related to the better relationship and better customer loyalty.

State control of banks has proven to be a stabilizing factor in financial crises of external origin, in contrast to the contraction in the supply of credit by private institutions (e.g., Allen et al., 2017; Behr et al., 2017; Brei \& Schclarek, 2013; Cull \& Martínez Pería (2013); Fungáčová et al., 2013; Micco \& Panizza, 2006).

In Brazil, some studies focusing on the 2008 international financial crisis suggest this counter-cyclical behavior. Pissetti (2012) uses aggregated data to show that stateowned banks' behavior was less pro-cyclical than private banks. Lundberg (2011) describes the increase in official banks' credit supply in the period, including the BNDES. In the same vein, Annibal et al. (2009) show that between 2008 and 2009, the participation of state-owned banks in total credit increased 9.7 p.p., a variation higher than the increase in their participation in the total deposits of the system. These conclusions are reinforced by Coleman and Feler's (2015) analysis, which uses panel data at the bank level and regressions with fixed effects and control variables.

Evidence is still scarce about the possible effects of earmarking on the stability of the credit supply. 


\section{RESEARCH DESIGN}

The study investigates the relationship between the dynamics of credit granting during the 2008 crisis and the following aspects: (i) the type of bank ownership (private or state-owned); (ii) the share of earmarked loans in total bank credits; (iii) the interaction between the type of property and the participation of earmarked credits; and (iv) the different funding of the two types of bank ownership.

\subsection{Data and Sample}

Quarterly accounting data from 2005 to 2012 are used for universal, commercials, investment, and savings banks, i.e., financial institutions that capture deposits from the public. Development banks (the largest of which is BNDES) are not part of the sample. The public accounting data were extracted from the Central Bank of Brazil (BCB) website in the report ' 50 largest banks and the consolidated system of the National Financial System. The information on the amounts of credit classified as free or earmarked was extracted from the Credit Information System (SCR), BCB's proprietary database.
The financial institutions in the sample may belong to conglomerates or be independent. In the first case, the accounting data refer to the holding company-level, following Gatev and Strahan (2006) and Kashyap, Rajan, and Stein (2002). For simplicity, each observational unit is called a bank.

Banks in which credit operations represent less than $1 \%$ of the assets and those that did not offer earmarked credits in the sample period were excluded from the analysis. Finally, banks that suffered intervention from the BCB due to accounting fraud were also excluded.

Acquisitions and mergers were treated as if the institutions formed after the event were a new company, according to Oliveira et al. (2015).

\subsection{Variables and Empirical Models}

To investigate the association between the type of bank ownership and the granting of credit during the financial crisis, Equation 1 (and variations described below) is estimated, where $i$ refers to the bank and $t$ to the quarter.

$$
\Delta E_{i, t}=\alpha_{1}+\alpha_{2} \text { Crisis }_{t}+\left(\alpha_{G 1}+\alpha_{G 2} \text { Crisis }_{t}\right) \text { Government }_{i, t}+\alpha_{0} \Delta E_{i, t-1}+\gamma^{\prime} \boldsymbol{B}_{i, t-1}+d_{t}+c_{i}+\varepsilon_{i, t}
$$

where $\Delta E=\Delta$ Loans or $\Delta$ Mandatory earmarked loans, as described in Table 1 . The volumes of credits granted in the "Rural," "Microcredit," and "Real estate" modalities under the source category of "earmarked" resources were used to analyze the dynamics of these mandatory earmarked credits specifically.

The indicator Crisis assumes the value 1 in the $3^{\text {rd }}$ and $4^{\text {th }}$ quarters of 2008 and the $1^{\text {st }}$ and $2^{\text {nd }}$ quarters of 2009 and zero in the other periods. At the end of the third quarter, 15 days had passed since the bankruptcy of Lehman Brothers bank in the United States in midSeptember 2008, but the disruption was such that it would not be reasonable to consider the whole quarter period without crisis. There is more controversy about the end of the acute phase of the crisis, positioned in previous works between the first and the second half of 2009. In the analyses reported below, June 2009 is considered the end of the period of greatest turbulence. However, in complementary analyses, alternative periods are considered to ensure that the research's main inferences are robust to variations in the definition of the critical period of the financial crisis.
The indicator Government assumes the value 1 when the bank is under the federal government's control or state governments and zero when control is private. Vector $\boldsymbol{B}$ contains the control variables representing the banks' economic fundamentals (Allen et al., 2017; Brei \& Schclarek 2013; Fucidji \& Prince, 2009; Kishan \& Opiela, 2000) and, depending on the estimated specification, their interactions with the crisis indicator variable. In the regressions reported in Table 3, vector $\boldsymbol{B}$ contains $\Delta$ Fundings (growth in funding), Liquidity, Quality of loans, Capitalization, Size, and ROA (a measure of profitability). The indicator of resource funding by banks used in this research is broader than in other previous studies, restricted to deposits (Allen et al., 2017; Brei \& Schclarek, 2013; Fucidji \& Prince, 2009). Also, Allen et al. (2017) and Brei and Schclarek (2013) do not control for loans' quality. In another similar work, Coleman and Feler (2015) do not include controls for profitability and funding growth. The unobserved heterogeneity of the banks is represented by $c_{i}$, the fixed effects of time by $d_{t}$, and the idiosyncratic error by $\varepsilon_{i, t}$. All variables are described in Table 1. 
Table 1

Description of the variables used in the research

\begin{tabular}{|c|c|}
\hline Variable & Description \\
\hline Crisis & Crisis $=1$ in the third and fourth quarters of 2008 and the first and second quarters of 2009 \\
\hline Government & Government $=1$ if the bank has state control and Government $=0$ otherwise \\
\hline Private & Private $=1$ if the bank has private control and Private $=0$ otherwise \\
\hline Earmarked participation & Total loans in earmarked category divided by total loans (free + earmarked) \\
\hline Mandatory earmarked participation & $\begin{array}{l}\text { Total "Rural", "Microcredit", and "Real Estate" loans from "earmarked" funds divided by total loans } \\
\text { (free + earmarked) }\end{array}$ \\
\hline$\Delta$ Loans & $\begin{array}{l}\text { Logarithmic variation between } t \text { and } t-1 \text { quarters of total loans granted by the financial institution, } \\
\text { adding up the balances in the free and earmarked categories }\end{array}$ \\
\hline$\Delta$ Mandatory earmarked loans & $\begin{array}{l}\text { Logarithmic variation between } t \text { and } t-1 \text { quarters of total loans in the "Rural," "Microcredit," and } \\
\text { "Real Estate" loans and from "earmarked" sources }\end{array}$ \\
\hline$\Delta$ Deposits & $\begin{array}{l}\text { Logarithmic variation between } t \text { and } t-1 \text { quarters of total deposits taken by the financial institution } \\
\text { (demand, time, interbank, savings, and others) }\end{array}$ \\
\hline$\Delta$ Fundings & $\begin{array}{l}\text { Logarithmic variation between } t \text { and } t-1 \text { quarters of total funding, including deposits (demand, } \\
\text { time, interbank, savings, and others), Repurchase Agreements; Real Estate, Mortgage, Credit, } \\
\text { Foreign Exchange, and Similar Bills; Funding by TVM Abroad; Other Resources and Obligations; } \\
\text { Bacen Rediscount; Obligations for Loans on Lending, Transfer, and Financial and Development } \\
\text { Funds; Foreign Exchange Operations with Funding Characteristics; Contracts for Assumption of } \\
\text { Obligations and Credits Linked to Transactions Acquired in Assignment }\end{array}$ \\
\hline Liquidity & $\begin{array}{l}\text { Net assets (Cash and Cash Equivalents, Interbank investments, Marketable Securities and Derivative } \\
\text { Financial Instruments, Interbank Relationships, Interdependence Relationships) divided by total } \\
\text { assets }\end{array}$ \\
\hline Quality of loans & Participation of credits rated $\mathrm{E}$ to $\mathrm{H}$ in the classified loan portfolio (low-quality loans) \\
\hline Capitalization & Shareholders' equity divided by total assets \\
\hline Size & Total assets logarithm \\
\hline ROA & Net income divided by total assets \\
\hline
\end{tabular}

Source: Prepared by the authors.

In Equation 1, $\alpha_{2}$ captures the change in the growth rate of loans from private banks during the acute phase of the crisis, compared to the base period. $\alpha_{G 1}$ coefficient represents the difference between the growth rates of loans from state-owned and private banks during the base period, while $\alpha_{G 2}$ captures the average difference in growth rates of loans between state-owned and private banks during the acute phase of the crisis in comparison with the base period.

Equation 2 is estimated to investigate the behavior of earmarked credit participation in the acute phase of the crisis:

$$
E P_{i, t}=\beta_{1}+\beta_{2} \text { Crisis }_{t}+\left(\beta_{P 1}+\beta_{P 2} \text { Crisis }_{t}\right) \text { Private }_{i, t}+\beta_{0} E P_{i, t-1}+\boldsymbol{\theta}^{\prime} \boldsymbol{B}_{i, t-1}+d_{t}+c_{i}+\varepsilon_{i, t}
$$

where $E P=$ earmarked proportion or mandatory earmarked proportion, as described in Table 1 . EP is replaced by $\triangle E P$ in alternative specifications, corresponding to the logarithmic variation in earmarked participation between quarters. Equation 2 investigates whether the share of earmarked credit increases during the crisis and whether this behavior is different for state-owned and private banks. $\beta$ coefficients have an interpretation similar to that described above for $\alpha$ coefficients. In particular, the hypothesis that the reduction of credit by private banks during the crisis was more pronounced, on average, in the free category than in the earmarked category is investigated. It is plausible that free credit is more sensitive to the deterioration in expectations caused by the financial crisis, at least for private banks. Furthermore, during the crisis, financial institutions could be attracted by the government's possible guarantees in operations of a earmarked nature, such as credit insurance (Torres Filho, 2009). 
Equation 3 is estimated to see whether, on average, banks with a greater share of earmarked in their loan portfolio increase more (or reduce less) the total amount of loans granted during the crisis and whether this behavior is different for state-owned banks and private. The coefficients of greatest interest, in this case, are $\delta_{5}$ and $\delta_{6}$.

$$
\begin{gathered}
\Delta E_{i, t}=\delta_{1}+\delta_{2} \text { Crisis }_{t}+\left(\delta_{3}+\delta_{4} \text { Crisis }_{t}\right) \text { Government }_{i, t}+\delta_{5} \text { EP }_{i, t-1} \text { Crisis }_{t}+\delta_{6} \text { EP }_{i, t-1} \text { Crisis }_{t} \text { Government }_{i, t} \\
+ \\
+\delta_{7} \text { EP }_{i, t-1} \text { Government }_{i, t}+\delta_{0} \Delta E_{i, t-1}+\delta_{8} E P_{i, t-1}+\boldsymbol{\phi}^{\prime} \boldsymbol{B}_{i, t-1}+d_{t}+c_{i}+\varepsilon_{i, t}
\end{gathered}
$$

During the crisis, a sharp increase in systemic risk perception led to small and medium-sized banks transferring deposits to systemically important banks (Oliveira et al., 2015). In a context of high uncertainty like that, banks could choose to preserve their liquidity at the expense of any other objectives, resulting in a severe reduction in credit granting to economic agents (De Paula \& Lima, 1999). Indeed, Schiozer and Oliveira (2016) report a reduction in the supply of credit in banks that had a negative shock in liquidity but found no increase in the supply of credit in banks that had a positive shock.

Thus, a natural concern is that funding dynamics have peculiarly affected credit supply during the crisis. For example, a state-controlled bank, which received an influx of resources during the crisis, would be more willing to offer credit. Likewise, banks that have raised little or even reduced funding (for example, those that have lost deposits) would have fewer resources available to lend. To address this issue, Equation 4 is estimated, which is a variation of Equation 1 to examine whether the difference in the growth rate of state-owned and private bank lending during the acute phase of the crisis can be explained by systematic differences in funding between the two types of banks in the same period.

$$
\begin{aligned}
& \Delta E_{i, t}=\omega_{1}+\omega_{2} \text { Crisis }_{t}+\left(\omega_{3}+\omega_{4} \text { Crisis }_{t}\right) \text { Government }_{i, t}+\omega_{5} \text { Frunding }_{i, t} \text { Crisis }_{t}+ \\
& \omega_{6} \Delta \text { Funding }_{i, t} \text { Crisis }_{t} \text { Government }_{i, t}+\omega_{7} \Delta \text { Funding }_{i, t} \text { Government }_{i, t}+\omega_{0} \Delta E_{i, t-1}+ \\
& \omega_{8} \Delta \text { Fundings } s_{i, t}+\boldsymbol{\pi}^{\prime} \boldsymbol{B}_{i, t-1}+d_{t}+c_{i}+\varepsilon_{i, t}
\end{aligned}
$$

In Equation 4, the variables of interest are the same as Equation 1 plus the interaction variables with $\Delta$ Fundings.

Equations 1 to 4 are estimated by the method of ordinary least squares (OLS) applied to panels and by the system generalized method of moments (GMMSys), described by Blundell and Bond (1998). The GMMSys allows isolating the effects of the unobserved and invariant component in time $c_{i}$ without the need to impose the restrictive assumption of strict exogeneity of the regressors, common to traditional methods of estimation with panel data.

Strict exogeneity is not a plausible assumption for most of the variables used in this research, starting with the lagged dependent variable, because it excludes the possibility that shocks on the dependent variable affect the regressors in the future. This feedback effect of the dependent variable for the regressors can significantly affect all banks' characteristics that vary over time. Also, some regressors can simultaneously influence and be influenced by the dependent variable. The simultaneity (or reverse causality) problem is especially plausible in models with $\Delta$ Fundings as an explanatory variable and $\Delta$ Loans as of the dependent variable.

The GMM-Sys allows specifying models in which the regressors are assumed to be "sequentially exogenous," using instrumental variables based on their own lagged values. This procedure can deal with feedback and simultaneity problems and help mitigate distortions in the estimates due to measurement errors of the regressors. The results of the Hansen test reported in the tables do not allow us to reject the null hypothesis of exogeneity of the set of lags used as instruments, and autocorrelation tests (not reported due to space savings) do not allow us to reject the null hypothesis of absence of autocorrelation in $\varepsilon_{i, t}$. Taken together, the various diagnostic procedures support the assumptions adopted in empirical modeling. 


\section{RESULTS}

The basic descriptive statistics of the variables used are in Table 2, separated by type of bank (private or stateowned) and period (acute crisis phase and other periods). The number of observations of the variables is not identical because they have different constructions, such as growth rate, proportion, and logarithm, in addition to missing data for some banks, and the number of these varies over time, with sample entries and exits. Table 2 shows the strong contraction of loans from private banks during the crisis, in contrast to the expansion of loans from state-owned banks, both in the total loans category and in the mandatory earmarked loans category. Also, there is a reduction in the average growth rate of deposits and, more sharply, in the growth rate of funding in general during the crisis compared to the other periods, mainly for private banks and state-owned banks. The average share of earmarked loans in total loans is similar in both periods for both state-owned and private banks.

Table 2

Descriptive statistics

\begin{tabular}{|c|c|c|c|c|c|c|c|c|c|c|c|c|}
\hline \multirow{2}{*}{ Variables } & \multicolumn{3}{|c|}{$\begin{array}{l}\text { Private banks: excluding } \\
\text { acute phase of the crisis }\end{array}$} & \multicolumn{3}{|c|}{$\begin{array}{c}\text { Private banks: acute phase of } \\
\text { the crisis }\end{array}$} & \multicolumn{3}{|c|}{$\begin{array}{l}\text { State-owned banks: } \\
\text { excluding acute phase of } \\
\text { the crisis }\end{array}$} & \multicolumn{3}{|c|}{$\begin{array}{l}\text { State-owned banks: acute } \\
\text { phase of the crisis }\end{array}$} \\
\hline & \# Obs. & Mean & $\begin{array}{l}\text { Standard } \\
\text { Deviation }\end{array}$ & \# Obs. & Mean & $\begin{array}{c}\text { Standard } \\
\text { Deviation }\end{array}$ & \# Obs. & Mean & $\begin{array}{l}\text { Standard } \\
\text { Deviation }\end{array}$ & \# Obs. & Mean & $\begin{array}{c}\text { Standard } \\
\text { Deviation }\end{array}$ \\
\hline $\begin{array}{c}\text { Earmarked } \\
\text { participation }\end{array}$ & 2,613 & 0.0991 & 0.176 & 334 & 0.0943 & 0.184 & 334 & 0.275 & 0.198 & 41 & 0.254 & 0.185 \\
\hline $\begin{array}{c}\text { Mandatory } \\
\text { earmarked } \\
\text { participation }\end{array}$ & 550 & 0.172 & 0.242 & 70 & 0.195 & 0.266 & 288 & 0.176 & 0.135 & 38 & 0.176 & 0.134 \\
\hline$\Delta$ Loans & 2,457 & 0.0483 & 0.364 & 321 & -0.0212 & 0.385 & 321 & 0.0475 & 0.0481 & 39 & 0.0704 & 0.0448 \\
\hline $\begin{array}{c}\Delta \text { Mandatory } \\
\text { earmarked loans }\end{array}$ & 505 & 0.0559 & 0.337 & 67 & 0.00299 & 0.136 & 273 & 0.0217 & 0.108 & 36 & 0.0423 & 0.114 \\
\hline$\Delta$ Deposits & 2,473 & 0.0443 & 0.590 & 324 & 0.0242 & 0.600 & 321 & 0.0415 & 0.0666 & 39 & 0.0327 & 0.0745 \\
\hline$\Delta$ Funding & 2,414 & 0.0451 & 0.375 & 315 & -0.00475 & 0.403 & 321 & 0.0411 & 0.0581 & 39 & 0.0254 & 0.0679 \\
\hline Liquidity & 2,606 & 0.281 & 0.197 & 334 & 0.274 & 0.193 & 334 & 0.371 & 0.143 & 41 & 0.366 & 0.123 \\
\hline Quality of loans & 2,508 & 0.0652 & 0.119 & 321 & 0.0790 & 0.127 & 334 & 0.0675 & 0.0344 & 41 & 0.0607 & 0.0267 \\
\hline Capitalization & 2,606 & 0.227 & 0.194 & 334 & 0.236 & 0.206 & 334 & 0.107 & 0.0694 & 41 & 0.101 & 0.0659 \\
\hline Size & 2,606 & 21.30 & 2.213 & 334 & 21.27 & 2.210 & 334 & 23.33 & 2.065 & 41 & 23.65 & 2.068 \\
\hline ROA & 2,581 & 0.673 & 3.798 & 326 & 0.323 & 2.809 & 334 & 1.132 & 0.722 & 41 & 1.197 & 0.732 \\
\hline
\end{tabular}

Note: This table shows basic descriptive statistics for the variables used in the regressions, separated by type of bank (private or state-owned) and period (acute phase of the crisis, $2^{\text {nd }}$ semester 2008 and $1^{\text {st }}$ semester 2009, and other periods). The variables are described in Table 1.

Source: Prepared by the authors.

Between 2005 and the beginning of the financial crisis, there was a more marked increase in the share of credit granted by private banks, mainly in the free category. Figure 1 shows the sharp reduction in the share of private credit with free resources, as well as the increase in the share of credit granted by state-owned banks. After the acute phase of the crisis, until the end of 2011, there was a relative stabilization with a more modest evolution in private credit.

Different specifications based on Equation 1 were estimated using the OLS and GMM-Sys methods (Table 3).
In these, time dummies are excluded to facilitate the interpretation of the crisis indicator variable's coefficient. The estimates in columns 1 and 2 show an average reduction of approximately 9 p.p. in the growth rate of total loans (in the free and earmarked categories) of the private banks in the sample during the acute phase of the crisis compared to the other periods, suggesting that the private banks significantly decreased the growth rate of lending in the period. The results, therefore, suggest that the financial crisis represented a turning point for the supply of private credit, as already shown in Figure 1. 


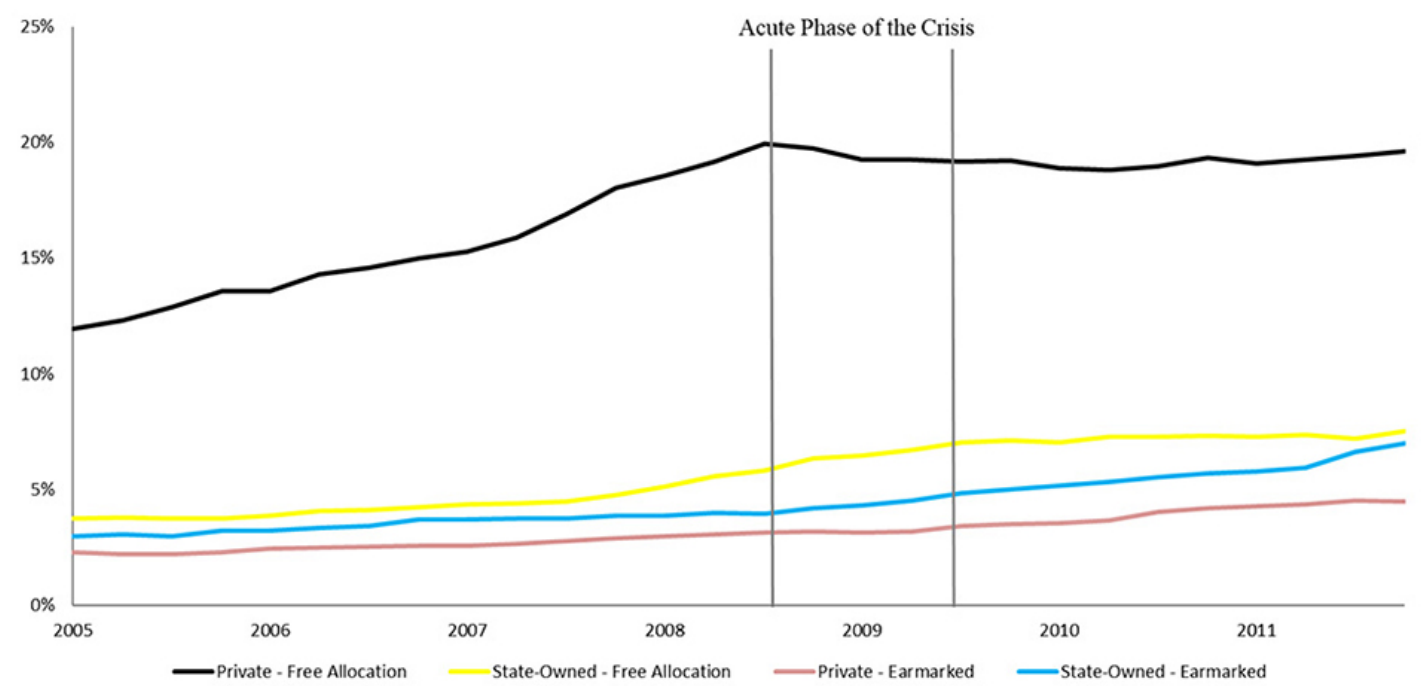

Figure 1 Evolution of credit as a percentage of GDP value by category (free and earmarked) and by type of control (state or private)

Source: Prepared by the authors.

In columns 3 and 4 of Table 3 , the variation rate focuses only on the mandatory earmarked loans from banks ("Rural," "Microcredit," and "Real estate" modalities originating from earmarked resources). In these specifications, the sample contains only the financial institutions that granted credit in the earmarked category, excluding those that met the requirements indirectly, for example, by acquiring securities from other banks linked to operations in the earmarked category. There is also a reduction in the growth rate of mandatory earmarked loans from private banks during the acute phase of the crisis compared to the other periods (in the model estimated using the GMM-Sys, the coefficient is positive, but not significant at conventional levels). While their magnitude is less than the reduction in the growth rate of total loans (approximately 5 p.p. compared to 9 p.p. of total loans), the distance between the coefficients is not statistically significant at conventional levels (for example, $95 \%$ confidence intervals of these coefficients are noted to overlap). This result suggests that the mandatory credit earmarking policies have not significantly contributed to softening private banks' retraction during the crisis's acute phase.

The estimated coefficients of the state control indicator variable (Government) are negative but not significant in the regressions estimated by GMM-Sys, suggesting that there is no statistically significant difference between the variation rates of loans (free or earmarked) granted by state-owned banks and in periods that exclude the acute phase of the crisis. A possible explanation for this result is that before the acute phase of the crisis, credit growth was more accelerated for private banks, and in the periods after the acute phase of the crisis, credit growth was more accelerated for state-owned banks.

The estimated coefficients for the Government $\mathrm{x}$ Crisis interaction are positive and significant at the $1 \%$ level in columns 1 and 2. The results reported in column 2 of Table 3 show a positive difference in the average growth rate of total loans during the acute phase of the crisis of approximately 12 p.p. for state-owned banks compared to private banks. This result is compatible with the conjecture that the crisis's negative shock on the credit supply was mitigated by increased state-owned banks' participation in the credit market.

Similarly, column 4 shows a positive difference in the average quarterly growth rate of obligatory earmarked loans during the acute phase of the crisis of approximately 7 p.p. for state-owned banks compared to private banks, keeping other factors constant. The sum of the estimated coefficients for the Crisis indicator variable and the Government $x$ Crisis interaction in columns 2 and 4 suggests an increase of around 3.5 p.p. and 1.1 p.p, respectively, in the average growth rate of loans for stateowned banks during the crisis compared to other periods.

However, the difference between these estimates is not statistically significant at conventional levels, suggesting no relevant difference in state-owned banks' behavior regarding the expansion of credits in the free or mandatory earmarked categories during the crisis. This conclusion is confirmed in alternative regressions using the variation of total loans as a dependent variable but excluding from the sample the banks that met the earmarking requirements indirectly. In these cases (not reported to save space), the interest coefficients' estimates have closer magnitudes. 
In regressions using total loans, the only control variable with significant coefficients at conventional levels is the Return on Assets (ROA). As expected, Table 3 reports a relevant and positive association between profitability and credit growth.

In regressions using only mandatory earmarked loans, there is a positive association (significant at the $5 \%$ level) with the proxy for size, suggesting that, on average, the larger banks expanded their mandatory earmarked loans further, keeping other factors constant. Positive associations with ROA are also observed in these regressions, suggesting that, on average, more profitable banks expanded mandatory earmarked loans further.

The results are qualitatively similar in other specifications (not reported), for example, using $\Delta$ Deposits in place of $\Delta$ Fundings or containing more control variables, including a complete set of time dummies and/ or interactions between all control variables (lagged) and the crisis dummy. Similarly, regressions were estimated with all controls set in the pre-crisis period. Alternative sets of instrumental variables (based on the regressors' lags) were used in the models estimated by GMM-Sys. The inclusion of more controls, in particular the interactions of liquidity indicators, loan quality, capitalization, size, and profitability with the crisis dummy, results in similar estimates of the Government $x$ Crisis interaction coefficient, suggesting that the reported association is not due to differences in the economic fundamentals of state-owned and private banks.

The conclusions are also not very sensitive to variations in the period considered as the acute phase of the crisis (for example, considering the fourth quarter of 2008 as the first of the acute phase of the crisis and/or as the end, the first, third and fourth quarters of 2009).

Table 3

Variation in loans in the acute phase of the crisis

\begin{tabular}{|c|c|c|c|c|}
\hline \multirow[b]{2}{*}{ Dependent variable } & $\Delta$ Loans & $\Delta$ Loans & $\Delta$ Earmarked Loans & $\Delta$ Earmarked Loans \\
\hline & (1) & (2) & (3) & (4) \\
\hline \multicolumn{5}{|l|}{ Variables of interest } \\
\hline \multirow{2}{*}{$\begin{array}{c}\text { Crisis (2 } 2^{\text {nd }} \text { sem. } 2008 \text { and } \\
\left.1^{\text {st }} \text { sem. } 2009\right)\end{array}$} & $-0.087 * * *$ & $-0.090^{* * *}$ & $-0.048^{* *}$ & -0.066 \\
\hline & $(-5.144)$ & $(-4.960)$ & $(-2.208)$ & $(-1.655)$ \\
\hline \multirow{2}{*}{ Government } & $-0.031 * *$ & -0.015 & -0.024 & -0.026 \\
\hline & $(-2.169)$ & $(-0.727)$ & $(-1.373)$ & $(-1.442)$ \\
\hline \multirow{2}{*}{ Government $x$ crisis } & $0.110^{* * *}$ & $0.125^{* * *}$ & $0.064^{*}$ & $0.077^{* *}$ \\
\hline & $(5.230)$ & $(4.378)$ & $(1.804)$ & $(2.073)$ \\
\hline \multicolumn{5}{|l|}{ Control variables } \\
\hline \multirow{2}{*}{ Dependent variable $(t-1)$} & -0.044 & -0.073 & 0.121 & 0.122 \\
\hline & $(-0.444)$ & $(-0.731)$ & (1.498) & $(1.479)$ \\
\hline \multirow{2}{*}{$\Delta$ Fundings $(\mathrm{t}-1)$} & 0.091 & 0.086 & 0.055 & 0.019 \\
\hline & $(1.631)$ & $(1.550)$ & $(0.576)$ & $(0.198)$ \\
\hline \multirow{2}{*}{ Liquidity $(t-1)$} & 0.075 & 0.061 & -0.006 & -0.004 \\
\hline & (1.189) & $(0.601)$ & $(-0.096)$ & $(-0.066)$ \\
\hline \multirow{2}{*}{ Quality of loans $(t-1)$} & -0.008 & -0.119 & $-0.359 *$ & -0.383 \\
\hline & $(-0.028)$ & $(-0.437)$ & $(-1.776)$ & $(-1.632)$ \\
\hline \multirow{2}{*}{ Capitalization $(\mathrm{t}-1)$} & 0.019 & 0.056 & -0.111 & -0.127 \\
\hline & $(0.232)$ & $(0.508)$ & $(-1.017)$ & $(-1.153)$ \\
\hline \multirow{2}{*}{ Size $(t-1)$} & 0.000 & -0.005 & $0.008^{* *}$ & $0.007^{* *}$ \\
\hline & (0.100) & $(-0.698)$ & (2.317) & (2.059) \\
\hline \multirow{2}{*}{$\mathrm{ROA}(\mathrm{t}-1)$} & $0.007^{* * *}$ & $0.007^{* *}$ & $0.011^{* * *}$ & $0.011^{* * *}$ \\
\hline & (2.765) & (2.513) & (2.828) & (2.902) \\
\hline
\end{tabular}


Table 3

Cont.

\begin{tabular}{|c|c|c|c|c|}
\hline & $\Delta$ Loans & $\Delta$ Loans & $\Delta$ Earmarked Loans & $\Delta$ Earmarked Loans \\
\hline Dependent variable & $\begin{array}{l}\text { (1) } \\
\text { OLS }\end{array}$ & $\begin{array}{c}\text { (2) } \\
\text { GMM-Sys }\end{array}$ & $\begin{array}{l}\text { (3) } \\
\text { OLS }\end{array}$ & $\begin{array}{c}\text { (4) } \\
\text { GMM-Sys }\end{array}$ \\
\hline \multirow{2}{*}{ Intercept } & 0.032 & 0.156 & -0.114 & -0.092 \\
\hline & $(0.450)$ & $(0.913)$ & $(-1.459)$ & $(-1.171)$ \\
\hline \# Observations & 2,230 & 2,230 & 696 & 696 \\
\hline \# Banks & 114 & 114 & 41 & 41 \\
\hline R-square & 0.042 & - & 0.034 & - \\
\hline$F(p$-value $)$ & $10.22(<0.001)$ & $9.691(<0.001)$ & $9.518(<0.001)$ & $9.202(<0.001)$ \\
\hline Hansen ( $p$-value) & - & $101.3(>.999)$ & - & $32.28(>.999)$ \\
\hline
\end{tabular}

Note: This table shows the results of Equation 1 estimates by ordinary least squares (OLS) and GMM-Systemic (one-step). The dependent variable is the variation rate (logarithmic) of bank loans (columns 1 and 2) or the variation rate (logarithmic) of mandatory earmarked loans from banks (columns 3 and 4). Table 1 presents the definitions of the variables. ( $t-1)$ indicates the first lag of the variable. The model estimated by GMM-Systemic assumes that the variables indicating the time and state property are strictly exogenous and that the other regressors are sequentially exogenous, using their lags as instrumental variables. Standard errors with grouping by the bank are used to compute robust $t$ statistics to arbitrary forms of autocorrelation and heteroskedasticity, reported in parentheses. * **, and *** indicate statistical significance at the levels of 10\%, 5\%, and $1 \%$, respectively.

Source: Prepared by the authors.

The set of results from the specifications based on Equation 2 shows that the share of earmarked credit concerning the total loan portfolio did not change significantly, on average, during the acute phase of the crisis for both state-owned and private banks (Table 4). The estimates of interest are not statistically different from zero at conventional levels.

While the visual inspection of Figure 1 suggests a slight increase in the share of earmarked credit in the private banks' portfolio during the acute crisis, this association is not statistically detectable, perhaps due to the low representativeness of earmarked credit concerning the total credit granted by many banks. As expected, the earmarked proportion is highly inertial, in a way that the past earmarked proportion explains most of this variable's contemporary variation among the banks in the sample.
The participation of mandatory earmarking is positively associated with the growth rate of funding ( $\Delta$ Fundings) and negatively with the proxies for liquidity, size, and ROA. However, the estimates for these coefficients are significant at conventional levels only in the model estimated via GMM-Sys.

As in the previous case, the results are qualitatively similar in alternative specifications, including models containing a complete set of time dummies, interactions between the control variables and the crisis dummy, $\Delta$ Deposits instead of $\Delta$ Fundings, use of fixed controls in the pre-crisis period, or variations in the period considered as the acute phase of the crisis. The main conclusions are also maintained when using the (logarithmic) variation rate of earmarked participation instead of this variable's level.

Table 4

Variation in the share of earmarked credit in the acute phase of the crisis

\begin{tabular}{ccccc}
\hline \multirow{2}{*}{ Dependent variable } & Earmarked participation & Earmarked participation & $\begin{array}{c}\text { Mandatory earmarked } \\
\text { participation }\end{array}$ & $\begin{array}{c}\text { Mandatory earmarked } \\
\text { participation }\end{array}$ \\
\cline { 2 - 5 } & $\begin{array}{c}(\mathbf{1}) \\
\text { OLS }\end{array}$ & $\begin{array}{c}(\mathbf{2}) \\
\text { GMM-Sys }\end{array}$ & $\begin{array}{c}\mathbf{( 3 )} \\
\text { OLS }\end{array}$ & GMM-Sys \\
\hline Variables of interest & & & & \\
\hline $\begin{array}{c}\text { Crisis }\left(2^{\text {nd }} \text { sem. 2008 and }\right. \\
1^{\text {st }} \text { sem. 2009) }\end{array}$ & -0.006 & -0.006 & -0.001 & 0.002 \\
\hline Private & $(-1.360)$ & $(-1.129)$ & $(-0.238)$ & $(0.683)$ \\
\cline { 2 - 5 } & 0.005 & 0.005 & -0.001 & -0.016 \\
\hline
\end{tabular}


Table 4

Cont.

\begin{tabular}{|c|c|c|c|c|}
\hline \multirow{2}{*}{ Dependent variable } & Earmarked participation & Earmarked participation & $\begin{array}{c}\text { Mandatory earmarked } \\
\text { participation }\end{array}$ & $\begin{array}{c}\text { Mandatory earmarked } \\
\text { participation }\end{array}$ \\
\hline & $\begin{array}{l}(1) \\
\text { OLS }\end{array}$ & $\begin{array}{c}(2) \\
\text { GMM-Sys }\end{array}$ & $\begin{array}{l}(3) \\
\text { OLS }\end{array}$ & $\begin{array}{c}(4) \\
\text { GMM-Sys }\end{array}$ \\
\hline \multirow{2}{*}{ Private $\mathrm{x}$ crisis } & 0.012 & 0.007 & -0.002 & -0.006 \\
\hline & $(1.253)$ & $(0.946)$ & $(-0.315)$ & $(-1.122)$ \\
\hline \multicolumn{5}{|l|}{ Control variables } \\
\hline \multirow{2}{*}{ Dependent variable $(t-1)$} & $0.979 * * *$ & $0.751^{* * *}$ & $0.991^{* * *}$ & $1.017^{* * *}$ \\
\hline & $(104.429)$ & (3.544) & $(168.140)$ & $(33.312)$ \\
\hline \multirow{2}{*}{$\Delta$ Fundings $(t-1)$} & -0.003 & -0.017 & 0.024 & $0.035^{* *}$ \\
\hline & $(-0.307)$ & $(-1.039)$ & (1.658) & (2.168) \\
\hline \multirow{2}{*}{ Liquidity $(t-1)$} & 0.029 & 0.118 & -0.022 & $-0.118^{* * *}$ \\
\hline & (1.009) & $(1.440)$ & $(-1.428)$ & $(-3.176)$ \\
\hline \multirow{2}{*}{ Capitalization $(\mathrm{t}-1)$} & -0.023 & -0.041 & -0.005 & -0.069 \\
\hline & $(-0.671)$ & $(-0.387)$ & $(-0.325)$ & $(-0.712)$ \\
\hline \multirow{2}{*}{ Quality of loans $(t-1)$} & -0.028 & -0.126 & 0.009 & 0.146 \\
\hline & $(-0.754)$ & $(-0.987)$ & $(0.384)$ & $(1.574)$ \\
\hline \multirow{2}{*}{ Size $(t-1)$} & -0.000 & 0.007 & -0.001 & $-0.011 * *$ \\
\hline & $(-0.033)$ & $(0.856)$ & $(-0.776)$ & $(-2.655)$ \\
\hline \multirow{2}{*}{$\mathrm{ROA}(\mathrm{t}-1)$} & -0.001 & 0.002 & 0.000 & $-0.002^{*}$ \\
\hline & $(-1.170)$ & $(0.583)$ & $(0.067)$ & $(-1.746)$ \\
\hline \multirow{2}{*}{ Intercept } & -0.001 & -0.136 & 0.021 & $0.295^{* *}$ \\
\hline & $(-0.037)$ & $(-0.770)$ & $(1.127)$ & $(2.697)$ \\
\hline \# Observations & 1.401 & 1.401 & 720 & 720 \\
\hline \# Banks & 74 & 74 & 41 & 41 \\
\hline R-square & 0.950 & - & 0.986 & - \\
\hline F (p-value) & $2,053(<0.001)$ & $30.31(<0.001)$ & $11,609(<0.001)$ & $273.9(<0.001)$ \\
\hline Hansen (p-value) & - & $60.50(>.999)$ & - & $32.71(>.999)$ \\
\hline
\end{tabular}

Note: This table shows the results of Equation 2 estimates by ordinary least squares (OLS) and GMM-Systemic (one-step). The dependent variable is the share of earmarked credit in the banks'total credit portfolio (columns 1 and 2) or the share of mandatory earmarked credit in the banks' total credit portfolio (columns 3 and 4). Table 1 presents the definitions of the variable. $(t-1)$ indicates the first lag of the variable. The model estimated by GMM-Systemic assumes that the variables indicating the time and private property are strictly exogenous and that the other regressors are sequentially exogenous, using their lags as instrumental variables. Standard errors with grouping by the bank are used to compute robust $t$ statistics to arbitrary forms of autocorrelation and heteroskedasticity, reported in parentheses. *,**, and *** indicate statistical significance at the levels of $10 \%$, $5 \%$, and $1 \%$, respectively.

Source: Prepared by the authors.

The estimated coefficients for the interactions between the dummies of crisis, state ownership, and earmarked participation (lagged) of Equation 3 are not significant at conventional levels in most cases, and their signs and magnitudes are sensitive to variations in the model specification (Table 5). These results suggest that the participation of banks' earmarking, whether state-owned or private, did not significantly affect their credit-granting growth rate (total) during the acute phase of the crisis. The results are qualitatively similar in alternative specifications similar to those previously mentioned. 
Table 5

Variation in loans in the acute phase of the crisis (September 2008 to June 2009) and earmarked credit participation

\begin{tabular}{|c|c|c|}
\hline \multirow[b]{2}{*}{ Dependent variable } & $\Delta$ Loans & $\Delta$ Loans \\
\hline & $\begin{array}{l}\text { (1) } \\
\text { OLS }\end{array}$ & $\begin{array}{c}\text { (2) } \\
\text { GMM-Sys }\end{array}$ \\
\hline \multicolumn{3}{|l|}{ Variables of interest } \\
\hline \multirow{2}{*}{ Crisis ( $2^{\text {nd }}$ sem. 2008 and $1^{\text {st }}$ sem. 2009) } & $-0.097^{* * *}$ & $-0.097 * * *$ \\
\hline & $(-4.813)$ & $(-4.630)$ \\
\hline \multirow{2}{*}{ Government } & $-0.030^{*}$ & 0.015 \\
\hline & $(-1.828)$ & $(0.342)$ \\
\hline \multirow{2}{*}{ Government $x$ crisis } & $0.105^{* * *}$ & $0.096^{* * *}$ \\
\hline & $(4.351)$ & $(3.662)$ \\
\hline \multirow{2}{*}{ Earmarked participation $(t-1) \times$ crisis } & $0.101^{* *}$ & 0.102 \\
\hline & $(2.075)$ & $(0.821)$ \\
\hline \multirow{2}{*}{$\begin{array}{c}\text { Earmarked participation }(\mathrm{t}-1) \mathrm{x} \text { crisis } \mathrm{x} \\
\text { government }\end{array}$} & -0.040 & -0.038 \\
\hline & $(-0.659)$ & $(-0.295)$ \\
\hline \multirow{2}{*}{ Earmarked participation $(t-1) \times$ government } & 0.014 & -0.207 \\
\hline & $(0.244)$ & $(-0.969)$ \\
\hline \multicolumn{3}{|l|}{ Control variables } \\
\hline \multirow{2}{*}{$\Delta$ Loans $(\mathrm{t}-1)$} & -0.045 & -0.025 \\
\hline & $(-0.448)$ & $(-0.413)$ \\
\hline \multirow{2}{*}{ Earmarked participation $(t-1)$} & -0.024 & 0.088 \\
\hline & $(-0.873)$ & $(0.466)$ \\
\hline \multirow{2}{*}{$\Delta$ Fundings $(t-1)$} & 0.090 & 0.070 \\
\hline & $(1.622)$ & $(1.171)$ \\
\hline \multirow{2}{*}{ Liquidity $(t-1)$} & 0.074 & 0.023 \\
\hline & $(1.151)$ & $(0.113)$ \\
\hline \multirow{2}{*}{ Quality of loans $(t-1)$} & -0.011 & -0.014 \\
\hline & $(-0.036)$ & $(-0.082)$ \\
\hline \multirow{2}{*}{ Capitalization $(\mathrm{t}-1)$} & 0.019 & 0.288 \\
\hline & $(0.227)$ & $(1.242)$ \\
\hline \multirow{2}{*}{ Size $(t-1)$} & 0.000 & 0.018 \\
\hline & $(0.112)$ & $(1.178)$ \\
\hline \multirow{2}{*}{$\mathrm{ROA}(\mathrm{t}-1)$} & $0.007^{* * *}$ & $0.008^{* * *}$ \\
\hline & $(2.736)$ & $(2.960)$ \\
\hline \multirow{2}{*}{ Intercept } & 0.034 & -0.396 \\
\hline & $(0.424)$ & $(-1.140)$ \\
\hline \# Observations & 2,230 & 2,230 \\
\hline \# Banks & 114 & 114 \\
\hline R-square & 0.043 & - \\
\hline$F(p$-value $)$ & $8.067(<0.001)$ & $6.437(<0.001)$ \\
\hline Hansen ( $p$-value) & - & $93.68(>.999)$ \\
\hline
\end{tabular}

Note: This table shows the results of Equation 3 estimates by ordinary least squares (OLS) and GMM-Systemic (one-step). The dependent variable is the variation rate (logarithmic) of bank loans. Table 1 presents the definitions of the variables. ( $t-1$ ) indicates the first lag of the variable. The model estimated by GMM-Systemic assumes that the variables indicating the time and state property are strictly exogenous and that the other regressors are sequentially exogenous, using their lags as instrumental variables. Standard errors with grouping by the bank are used to compute robust $t$ statistics to arbitrary forms of autocorrelation and heteroskedasticity, reported in parentheses. ${ }^{*}, * *$, and ${ }^{* * *}$ indicate statistical significance at the levels of $10 \%, 5 \%$, and $1 \%$, respectively.

Source: Prepared by the authors. 
The growth rate of total loans is sensitive to the growth rate of funding, and this sensitivity increased substantially during the crisis so that the banks that raised the most funds during this period tended to expand more or to contract less their credit. The estimated coefficients for $\Delta$ Fundings $\mathrm{x}$ Crisis interaction of Equation 4 are positive and significant at the $1 \%$ level in all regressions (Table 6). The coefficients estimated for $\Delta$ Fundings are also positive and significant at conventional levels. In turn, the estimated coefficients for $\Delta$ Fundings $\mathrm{x}$ Crisis $x$ Government interaction are unstable and not significant at conventional levels, suggesting that the greater association between the growth rate of funding and the growth rate of total loans during the acute phase of the crisis was similar for state-owned and private banks.
The estimated coefficients for the other variables of interest shown in Table 6 are similar to those reported in Table 3, suggesting that the associations between the type of property and the credit behavior during the acute phase of the crisis are not fully explained by differences in funding resources in the same period. In particular, the estimates related to the Crisis and Government $\mathrm{x}$ Crisis dummies remain significant and with magnitudes similar to those reported in Table 3. These inferences are maintained in alternative specifications similar to those previously mentioned, including among the controls the first $\Delta$ Fundings lag and its interactions with the crisis and property type variables. The inferences that state-owned banks are the main credit providers in the crisis are similar in the regressions (not reported) that use the variation of mandatory earmarked loans as a dependent variable.

Table 6

Variation in loans in the acute phase of the crisis and participation of earmarked credit

\begin{tabular}{|c|c|c|}
\hline \multirow[b]{2}{*}{ Dependent variable } & $\Delta$ Loans & $\Delta$ Loans \\
\hline & $\begin{array}{l}\text { (1) } \\
\text { OLS }\end{array}$ & $\begin{array}{c}(2) \\
\text { GMM-Sys }\end{array}$ \\
\hline \multicolumn{3}{|l|}{ Variables of interest } \\
\hline \multirow{2}{*}{ Crisis ( $2^{\text {nd }}$ sem. 2008 and $1^{\text {st }}$ sem. 2009) } & $-0.079 * * *$ & $-0.082^{* * *}$ \\
\hline & $(-5.767)$ & $(-5.755)$ \\
\hline \multirow{2}{*}{ Government } & $-0.041^{* * *}$ & -0.025 \\
\hline & $(-2.627)$ & $(-0.600)$ \\
\hline \multirow{2}{*}{ Government $x$ crisis } & $0.106^{* * *}$ & $0.098^{* * *}$ \\
\hline & (5.304) & (5.750) \\
\hline \multirow{2}{*}{$\Delta$ Fundings $x$ crisis } & $0.275^{* * *}$ & $0.293^{* * *}$ \\
\hline & $(2.994)$ & $(3.214)$ \\
\hline \multirow{2}{*}{$\Delta$ Fundings $x$ crisis $x$ government } & -0.318 & -0.382 \\
\hline & $(-1.551)$ & $(-1.655)$ \\
\hline \multirow{2}{*}{$\Delta$ Fundings $x$ government } & 0.032 & 0.074 \\
\hline & $(0.261)$ & $(0.648)$ \\
\hline \multicolumn{3}{|l|}{ Control variables } \\
\hline \multirow{2}{*}{$\Delta$ Loans $(\mathrm{t}-1)$} & -0.021 & -0.011 \\
\hline & $(-0.260)$ & $(-0.230)$ \\
\hline \multirow{2}{*}{$\Delta$ Fundings } & $0.154^{* * *}$ & $0.121^{* *}$ \\
\hline & $(2.737)$ & $(2.349)$ \\
\hline \multirow{2}{*}{ Liquidity $(\mathrm{t}-1)$} & $0.106^{*}$ & 0.059 \\
\hline & $(1.707)$ & $(0.258)$ \\
\hline \multirow{2}{*}{ Quality of loans (t-1) } & 0.047 & 0.196 \\
\hline & $(0.152)$ & $(0.676)$ \\
\hline \multirow{2}{*}{ Capitalization $(\mathrm{t}-1)$} & -0.042 & 0.126 \\
\hline & $(-0.578)$ & $(0.543)$ \\
\hline \multirow{2}{*}{ Size $(t-1)$} & -0.001 & 0.003 \\
\hline & $(-0.397)$ & $(0.172)$ \\
\hline \multirow{2}{*}{$\mathrm{ROA}(\mathrm{t}-1)$} & $0.007^{* * *}$ & $0.010^{* * *}$ \\
\hline & (2.879) & (2.677) \\
\hline
\end{tabular}


Table 6

Cont.

\begin{tabular}{|c|c|c|}
\hline \multirow[b]{2}{*}{ Dependent variable } & $\Delta$ Loans & $\Delta$ Loans \\
\hline & $\begin{array}{l}\text { (1) } \\
\text { OLS }\end{array}$ & $\begin{array}{c}\text { (2) } \\
\text { GMM-Sys }\end{array}$ \\
\hline \multirow{2}{*}{ Intercept } & 0.060 & -0.059 \\
\hline & $(0.900)$ & $(-0.148)$ \\
\hline \# Observations & 2,229 & 2,229 \\
\hline \# Banks & 114 & 114 \\
\hline R-square & 0.108 & - \\
\hline$F$ (p-value) & $13.54(<0.001)$ & $9.515(<0.001)$ \\
\hline Hansen (p-value) & - & $101.5(>.999)$ \\
\hline
\end{tabular}

Note: This table shows the results of Equation 4 estimates by ordinary least squares (OLS) and GMM-Systemic (one-step). The dependent variable is the variation rate (logarithmic) of bank loans. Table 1 presents the definitions of the variables. ( $t-1)$ indicates the first lag of the variable. The model estimated by GMM-Systemic assumes that the variables indicating the time and state property are strictly exogenous and that the other regressors are sequentially exogenous, using their lags as instrumental variables. Standard errors with grouping by the bank are used to compute robust $t$ statistics to arbitrary forms of autocorrelation and heteroskedasticity, reported in parentheses. ${ }^{*}, * *$, and ${ }^{* * *}$ indicate statistical significance at the levels of $10 \%, 5 \%$, and $1 \%$, respectively.

Source: Prepared by the authors.

\section{FINAL REMARKS}

This research investigates the role of earmarking policies and corporate control (state or private) in the granting of bank credit in Brazil during the 2008 global financial crisis. The crisis offers an interesting context to investigate this phenomenon because it was largely exogenous concerning the domestic financial system and the demand for credit from many economic agents. At the same time, the perception of uncertainty in the financial sector increased sharply. Considering the research scope, the sample includes financial institutions that raise funds from the public, thus excluding development banks, such as the BNDES. The important direct action of the BNDES during the 2008 crisis is addressed in other studies, such as by Annibal et al. (2009).

The results indicate that private banks significantly reduced their lending during the crisis. The retraction was more pronounced for loans in the free category. Stateowned banks, in contrast, expanded their lending in the same period, possibly operating countercyclically. While the growth rate of loans was higher for the banks that raised the most funds during the crisis, this association does not fully explain the difference in behavior between private and state-owned banks in the period, suggesting an effect of corporate control independent of economic and financial fundamentals concerning banks' funding.

As Brei and Schclarek (2013) argue, this behavior may reflect differences in the objective function and implicit state protection between state-owned and private banks. Nevertheless, even the largest private banks (presumably "too big to fail") substantially reduced their credit supply, combined with the control of growth in funding in regressions, favors the conjecture that state-owned banks implemented a counter-cyclical policy during the 2008 crisis.

The evidence presented in this research is compatible with that reported in other countries in the same period and suggests that banks under state control may smooth out credit contraction during financial turbulence and economic cycles. Our results do not imply that the performance of state-owned banks is always positive for the economy. There is, for example, evidence that these banks can be used for political purposes and act inefficiently (e.g., Carvalho, 2014; Coleman \& Feler, 2015; Megginson, 2005; Sapienza, 2004). It is beyond this research's scope to assess the effects of state-owned banks' counter-cyclical actions (and pro-cyclical of private banks) on their performance and the financial system's health. These effects remain a relevant issue for future studies.

There was no statistically significant increase in the participation of earmarked loans in the total of loans granted by private or state-owned banks. In the same vein, the average growth rate of loans during the crisis does not appear to have been significantly affected by the degree of prior participation in earmarked credits. 
Taken as a whole, this evidence, unprecedented in the banking literature, suggests a second-order importance of earmarking in the smoothing of credit contraction resulting from the financial crisis.

\section{REFERENCES}

Allen, F., Jackowicz, K., Kowalewski, O., \& Kozłowski, Ł. (2017). Bank lending, crises, and changing ownership structure in Central and Eastern European countries. Journal of Corporate Finance, 42, 494-515.

Annibal, C., Lundberg, E., \& Koyama, S. M. (2009). Crise de 2008 e as mudanças no mercado de crédito. Relatório de Economia Bancária e Crédito, 37-52.

Banco Central do Brasil (BCB) (2014). Recolhimentos compulsórios, encaixe e direcionamentos obrigatórios. Retrieved from http://www.bcb.gov.br/?COMPULSORIOS

Banco Nacional de Desenvolvimento Econômico e Social (BNDES) (2014). Instituições Financeiras Credenciadas. Retrieved from https://www.bndes.gov.br/wps/portal/site/ home/instituicoes-financeiras-credenciadas/

Behr, P., Foos, D., \& Norden, L. (2017). Cyclicality of SME lending and government involvement in banks. Journal of Banking \& Finance, 77, 64-77.

Blundell, R., \& Bond, S. (1998). Initial conditions and moment restrictions in dynamic panel data models. Journal of Econometrics, 87(1), 115-143.

Bonomo, M., Brito, R., \& Martins, B. (2014). Macroeconomic and financial consequences of the after crisis government-driven credit expansion in Brazil. Banco Central do Brasil Working Paper Series, (378).

Brei, M., \& Schclarek, A. (2015). A theoretical model of bank lending: Does ownership matter in times of crisis? Journal of Banking \& Finance, 50, 298-307.

Brei, M., \& Schclarek, A. (2013). Public bank lending in times of crisis. Journal of Financial Stability, 9(4), 820-830.

Carvalho, D. (2014). The real effects of government-owned banks: Evidence from an emerging market. Journal of Finance, 69(2), 577-609.

Chen, Y. S., Chen, Y., Lin, C. Y., \& Sharma, Z. (2016). Is there a bright side to government banks? Evidence from the global financial crisis. Journal of Financial Stability, 26, 128-143.

Coleman, N., \& Feler, L. (2015). Bank ownership, lending, and local economic performance during the 2008-2009 financial crisis. Journal of Monetary Economics, 71, 50-66.

Cull, R., \& Martinez Pería, M. S. (2013). Bank ownership and lending patterns during the 2008-2009 financial crisis: evidence from Latin America and Eastern Europe. Journal of Banking \& Finance, 37(12), 4861-4878.

De Paula, L. F., \& Lima, G. T. (1999). Teoria da firma bancária. In G. T. Lima et al. Macroeconomia moderna: Keynes e a economia contemporânea. Rio de Janeiro: Campus.

Dinç, I. S. (2005). Politicians and banks: Political influences on government-owned banks in emerging markets. Journal of Financial Economics, 77(2), 453-479.
Fucidji, J. R., \& Prince, D. D. (2009). Determinantes do crédito bancário: uma análise com dados em painel para as maiores instituições. Análise Econômica, 27(52), 233-251.

Fungáčová, Z., Herrala, R., \& Weill, L. (2013). The influence of bank ownership on credit supply: evidence from the recent financial crisis. Emerging Markets Review, 15, 136-147.

Gatev, E., \& Strahan, P. E. (2006). Banks' advantage in hedging liquidity risk: Theory and evidence from the commercial paper market. Journal of Finance, 61(2), 867-892.

Kashyap, A. K., Rajan, R., \& Stein, J. C. (2002). Banks as liquidity providers: An explanation for the coexistence of lending and deposit-taking. Journal of Finance, 57(1), 33-73.

Kishan, R. P., \& Opiela, T. P. (2000). Bank size, bank capital, and the bank lending channel. Journal of Money, Credit and Banking, 32(1), 121-141.

La Porta, R., Lopez-de-Silanes, F., \& Shleifer, A. (2002). Government ownership of banks. The Journal of Finance, 57(1), 265-301.

Llanto, G. M., Geron, P., \& Tang, C. (1999). Directed credit programs: issues and framework for reform. Manila: Credit Policy Improvement Program.

Lundberg, E. L. (2011). Bancos oficiais e crédito direcionado - o que diferencia o mercado de crédito brasileiro? Banco Central do Brasil Working Paper Series, (258).

Megginson, W. L. (2005). The economics of bank privatization. Journal of Banking \& Finance, 29(8-9), 19311980.

Micco, A., \& Panizza, U. (2006). Bank ownership and lending behavior. Economics Letters, 93(2), 248-254.

Oliveira, R. F., Schiozer, R., \& Barros, L. A. B. C. (2015). Depositors' perception of "too-big-to-fail". Review of Finance, 19(1), 191-227.

Pissetti, J. A. W. (2012). The 2008 financial crisis and its effects on credit supply in the Brazilian banking system: The stabilizing role of public banks. Competence Centre on Money, Trade, Finance and Development Working Papers, (1209).

Sapienza, P. (2004). The effects of government ownership on bank lending. Journal of Financial Economics, 72(2), 357-384.

Schiozer, R., \& Oliveira, R. F. (2016). Asymmetric transmission of a bank liquidity shock. Journal of Financial Stability, 25, 234-246.

Stiglitz, J. E. (1993). The role of the state in financial markets. The World Bank Economic Review, 7(1), 19-52.

Torres Filho, E. T. (2009). Mecanismos de direcionamento do crédito, bancos de desenvolvimento e a experiência recente do BNDES. In F. M. R. Ferreira e B. B. Meirelles (Orgs.), Ensaios sobre economia financeira (pp. 11-56). Rio de Janeiro, RJ: BNDES. 